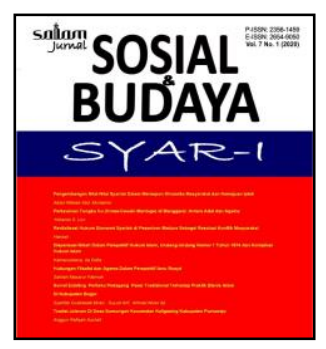

P-ISSN: 2356-1459. E-ISSN: 2654-9050

Vol. 8 No. 2 (2021), pp. 515-532

DOI: 10.15408/sjsbs.v8i2.19896

http://journal.uinikt.ac.id/index.php/salam/index

\title{
Penguatan Merger Bank Syariah BUMN dan Dampaknya Dalam Stabilitas Perekonomian Negara*
}

\author{
Ika Atikah', Maimunah' ${ }^{2}$, Fuad Zainuddin ${ }^{3}$ \\ UIN Sultan Maulana Hasanuddin Banten \\ d. \\ $10.15408 /$ sjsbs.v8i2.19896
}

\begin{abstract}
This study provides an overview of strengthening the merger of state-owned sharia banks, namely BNI Syariah, BSM, BRI Syariah which merged into Bank Syariah Indonesia (BSI). The purpose of the study was to determine the legal arrangements for strengthening the merger of Islamic banks to become BSI and its impact on the stability of state finances during the COVID-19 pandemic. The research method used in this study uses normative research with a statutory approach and a conceptual approach. Primary sources of law use legal regulations related to mergers of banking institutions and secondary sources of law from several kinds of literature such as journals and books relating to the issues being discussed. Meanwhile, legal material analysis techniques are used descriptively. The result of the research is the strengthening of the merger of BUMN Islamic banks starting with the existence of an agreement that is outlined in the written form of an Islamic commercial bank merger agreement as regulated in several applicable legal regulations. The merger of Islamic commercial banks during a pandemic is the right step to maintain the country's economic stability, as stated in Perpu No.1 / 2020 and POJK No.18 / POJK.03 / 2020. The impact of the merger of Islamic commercial banks, of course, has a positive impact, Indonesian Islamic banks can compete globally by prioritizing more complete services, wider coverage, and better capitalization. For the state, it is certainly a good thing that can be done by the Ministry of BUMN, by initiating the merger of 3 sharia-based state-owned subsidiaries (BNI Syariah, BSM, BRI Syariah) merging into PT. Bank Syariah Indonesia, Tbk.
\end{abstract}

Keywords: Merger, Sharia Banks, Finance

\begin{abstract}
Abstrak
Penelitian ini memberikan gambaran tentang penguatan penggabungan bank syariah BUMN yaitu BNI Syariah, BSM, BRI Syariah yang melebur menjadi Bank Syariah Indonesia (BSI). Tujuan dari penelitian untuk mengetahui pengaturan hukum terhadap penguatan merger bank syariah menjadi BSI dan dampaknya dalam stabilitas keuangan negara di tengah pandemi COVID-19. Metode penelitian yang digunakan dalam penelitian ini menggunakan penelitian normatif dengan pendekatan perundang-undangan dan pendekatan konseptual. Sumber hukum primer menggunakan peraturan hukum terkait merger lembaga perbankan dan sumber hukum sekunder dari beberapa literatur seperti
\end{abstract}

* Received: January 25, 2021, Revision: January 30, 2021, Published: April 1, 2021.

${ }^{1}$ Ika Atikah adalah dosen Fakultas Syariah UIN Sultan Maulana Hasanuddin Banten, Serang, Banten Indonesia, alamat email: ika.atikah@uinbanten.ac.id

${ }^{2}$ Maimunah adalah dosen Fakultas Tarbiyah dan Keguruan UIN Sultan Maulana Hasanuddin Banten, Serang, Banten Indonesia, alamat email : maimuna@uinbanten.ac.id

${ }^{3}$ Fuad Zainuddin adalah dosen Fakultas Syariah UIN Sultan Maulana Hasanuddin Banten, Serang, Banten Indonesia, alamat email: fuad.zainuddin@uinbanten.ac.id 
jurnal dan buku berkaitan dengan permasalahan yang sedang dibahas. Sedangkan teknik analisis bahan hukum menggunakan deskriptif. Hasil dari penelitian adalah penguatan penggabungan bank syariah BUMN dimulai dengan adanya kesepakatan yang dituangkan dalam bentuk tertulis perjanjian penggabungan bank umum syariah sebagaimana diatur dalam beberapa peraturan hukum yang berlaku. Penggabungan bank umum syariah di tengah pandemi, menjadi langkah tepat guna menjaga stabilitas ekonomi negara sebagaimana Perppu No.1/2020 dan POJK No.18/POJK.03/2020. Dampak dari penggabungan bank umum syariah, tentunya memberikan dampak positif, bank syariah Indonesia mampu bersaing secara global dengan mengedepankan layanan yang lebih lengkap, jangkauan menjadi lebih luas, dan permodalan menjadi lebih baik. Bagi negara, tentunya menjadi hal baik yang dapat dilakukan oleh kementerian BUMN, dengan menggagas merger 3 anak perusahaan milik negara berbasis syariah (BNI Syariah, BSM, BRI Syariah) melebur menjadi PT. Bank Syariah Indonesia, Tbk.

Kata Kunci: Merger, Bank Syariah, Keuangan

\section{A. Pendahuluan}

Bank syariah sebagai salah satu lembaga keuangan ekonomi syariah yang paling banyak diminati dan eksistensinya telah diakui di sejumlah negara. Kehadirannya, sangatlah memberikan perubahan sistem ekonomi di era globalisasi digital. Sebut saja negara Malaysia, Singapura, Arab Saudi, Mesir, Sudan, Pakistan, Inggris, Jerman dan masih banyak negara lainnya yang telah berdiri lembaga keuangan syariah melalui pendirian perusahan bank syariah. Hingga 2014, tercatat asset perbankan syariah di pasar global secara keseluruhan telah mencapai US \$ 778 Miliar, yaitu pangsa pasar bank syariah secara global meliputi Malaysia, Bahrain, Kuwait, Qatar, Uni Emirat Arab, dan Arab Saudi. ${ }^{4}$

Cikal bakal perkembangan perbankan syariah terjadi di awal tahun 1980-an, dengan berdirinya Bank Islam Malaysia Berhad (BIMB) di tahun 1983. Di Indonesia sendiri, bank syariah pertama kali beroperasi resmi di tahun 1992. Pemikiran terkait hal ini sudah ada sejak tahun 1970-an. Menurut Dawam Raharjo, yang melatar belakangi sistem keuangan terhambat adalah faktor politik, yaitu bahwa pendirian bank syariah dianggap sebagai suatu bagian dari cita-cita negara Islam. ${ }^{5}$ Seiring perkembangan bank syariah di Indonesia meningkat pesat, hal ini terlihat hingga akhir tahun 2019 saja terdapat 14 bank umum syariah, 20 unit usaha syariah, dan 164 BPRS. Penambahan jumlah bank umum syariah terjadi pasca Undang-Undang Perbankan Syariah No.21 Tahun 2008. ${ }^{6}$ Kebijakan aturan hukum yang diterbitkan oleh negara, sebagai upaya perlindungan hukum segala transaksi bank syariah di Indonesia.

4 Aisyah (2017) Perkembangan Perbankan Syariah di Inggris, http://www.ibecfebui.com/perkembangan-perbankan-syariah-di-inggris/ 23 Februari 2021

5 Halil Khusairi, Hukum Perbankan Syariah, Al-Qishthu Volume 13, Nomor 12015 ISSN : 18581099 http://jurnal.fs.iainkerinci.ac.id/index.php/alqisthu/article/viewFile/9/2 23 February 2021

${ }^{6}$ M.Nur Rianto Al Arif, dkk, The Alternative Strategies for Accelerating Islamic Banking Growth: Mergers, Spin-Offs, Acquisitions and Conversions, Jurnal Al-Ulum Vol. 20 No.1 (2020), https://doi.org/10.30603/au.v20i1.1171, p.25 23 Februari 2021 
Bank syariah menjauhi riba dan tidak mengenal istilah bunga. Prinsip utama dari bank syariah adalah melarang menerapkan riba apapun bentuk transaksinya. ${ }^{7}$ Oleh karenanya, penerapan bank syariah tidak terlepas dari sumber hukum Islam baik alQur'an, al-Hadist, hingga aturan yang dikeluarkan oleh pemerintah Indonesia dalam bentuk perundang-undangan yang hingga kini masih tetap berlaku dan terpisah dari aturan bank konvensional.

Tidak hanya bank syariah swasta, bank syariah milik negara (BUMN) ikut memberikan sumbangsih bagi perekonomian negara Indonesia. Kehadiran BNI Syariah, Bank Syariah Mandiri, BRI Syariah, telah memberikan warna tersendiri sebagai bank ber plat merah kepada masyarakat yang berfungsi sebagai kelembagaan bank syariah, menjembatani antara pihak pemilik modal dengan pihak yang membutuhkan dana, juga memiliki fungsi khusus secara amanah, artinya berkewajiban menjaga dan bertanggung jawab atas keamanan dana yang disimpan dan siap kapanpun dana dapat diambil pemiliknya.

Pada akhir tahun 2020, pemerintah Indonesia melalui Menteri BUMN mengumumkan bahwa, akan terjadi penggabungan (merger) 3 bank syariah BUMN yaitu BNI Syariah, BRI Syariah, dan Bank Syariah Mandiri menjadi Bank Syariah Indonesia. Merger tersebut dilakukan di tengah pandemi covid-19. Proses penggabungan 3 Bank Syariah tersebut ditandai dengan kesepakatan yang tertuang dalam akta penggabungan. Di tahun 2021, tepatnya pada tanggal 01 Februari, ketiga bank syariah (BNI Syariah, BRI Syariah, dan Bank Mandiri Syariah) resmi menjadi Bank Syariah Indonesia.

Penggabungan tiga bank umum syariah, perusahaan milik negara, menjawab penantian panjang untuk membentuk yang terbesar bank umum syariah nasional dengan modal kuat. Merger tersebut menjelaskan bahwa merger ini memiliki visi dari perbankan syariah nasional menjadi salah satu dari 10 bank syariah terbesar berdasarkan kapitalisasi pasar global dalam 5 tahun ke depan. ${ }^{8}$ Merger sendiri memiliki makna sebagai serikat bisnis, sehingga tercapai kepemilikan bersama. Strategi merger antar bank syariah dikategorikan sebagai merger horizontal.

Sebenarnya, merger bank bukanlah suatu hal baru dilakukan, mengangkat masalah kebijakan publik. Pada tahun 1950-an, gerakan merger besar-besaran telah memicu kekhawatiran akan konsolidasi yang belum pernah terjadi sebelumnya di sektor keuangan. Banyak dari kesepakatan ini tidak membutuhkan persetujuan lembaga berwenang. Beberapa tahun kemudian, Kongres membentuk rezim pengawasan yang secara komprehensif untuk merger bank sebagai upaya pengendalian konsolidasi yang tidak diatur. ${ }^{9}$ Dalam hal ini bukan berarti bahwa

7 Ika Atikah, (2018) Peran Pemerintah Terhadap Proteksi Hak-Hak Konsumen dalam Transaksi Ekonomi Syariah. Prosiding Seminar Nasional Prodi Hukum Ekonomi Syariah Universitas Muhammadiyah Purwokerto, http://digital.library.ump.ac.id/17/ 23 Februari 2021

${ }^{8}$ Agus Hartanto \& Nur Fatwa, The Geostrategy of Sharia Banking Merger in Indonesia, Scientific Research Journal (SCIRJ), Volume VIII, Issue XII, December 202060 ISSN 2201-2796 www.scirj.org @ 2020, Scientific Research Journal http://dx.doi.org/10.31364/SCIRJ/v8.i12.2020.P1220829

9 Jeremy C. Kress, Modernizing Bank Merger Review, 37 YALE J. ON Reg. (2020). Available at: https://digitalcommons.law.yale.edu/yjreg/vol37/iss2/2 23 Februari 2021 
merger bank pada dasarnya bermasalah. Dalam beberapa kasus, merger dapat menciptakan penghematan biaya, yang dapat diteruskan oleh bank kepada konsumen. Memang, menurut beberapa studi empiris, bank mengalami skala ekonomi. Selain itu, skala telah menjadi semakin penting dalam beberapa tahun terakhir, karena bank banyak berinvestasi dalam teknologi. ${ }^{10}$ Sejalan dengan intuisi ini, beberapa studi telah menemukan bahwa merger, khususnya bank-bank terkecil menghasilkan penghematan biaya. Oleh karena itu, dengan pengawasan yang tepat, merger bank dapat menguntungkan institusi itu sendiri dan pelanggannya. ${ }^{11}$

Tak dapat dihindarkan, merger bank memunculkan pertanyaan yang berkaitan dengan manfaat nilai tambah yang lebih tinggi. Pertanyaan muncul yang didasari oleh beberapa penelitian terkait merger bank di sejumlah negara. Studi dilakukan oleh Calomiris dan Karceski, ada empat hal penting dari Sembilan kasus merger bank di Amerika Serikat, pertama, proses merger menciptakan nilai tambah bagi industri perbankan secara komprehensif, kedua, ada beberapa bank hasil merger mengalami kegagalan akibat penurunan pendapatan yang drastis selama proses konsolidasi, ketiga, perilaku manajemen bank yang akan di merger menimbulkan kenaikan biaya yang tidak perlu. Kenaikan gaji dan pangkat sebelum merger agar mendapatkan posisi yang lebih baik setelah merger merupakan salah satu fenomena yang terjadi, dan keempat sinergi pendapatan dapat terlaksana meskipun tidak ada efisiensi biaya. Penggabungan bank khususnya bagi bank memiliki cabang yang mana lokasi tumpang tindih, sesuatu yang tidak mudah dilakukan. Selain itu, masalah nasabah peminjaman skala kecil seringkali terabaikan dalam proses merger, meskipun merger menimbulkan efisiensi penurunan suku bunga bank hasil merger. Studi yang dilakukan Harada dan Ito, kasus merger bank menghasilkan bank lemah dan dalam beberapa bank hasil merger, distance to default justru memburuk. ${ }^{12}$

Pengawasan terhadap merger bank syariah, menjadi tugas dan wewenang Otoritas Jasa Keuangan sehingga implementasi dari merger 3 (tiga) bank syariah BUMN dapat memberikan sumbangsih bagi masyarakat dan juga perekonomian negara. Peluang merger bank syariah milik negara, tentunya berimbas pada stabilitas ekonomi negara di tengah pandemi. Ekonomi menjadi lambat selama covid-19 telah menjadi penyakit yang tak kunjung hilang dari Indonesia, sehingga pemerintah mengeluarkan kebijakan Peraturan Pemerintah Pengganti Undang-Undang (Perppu) No.1/2020 tentang Kebijakan Keuangan Negara dan Stabilitas Sistem Keuangan Penanganan Pandemi Covid-19, dalam rangka menghadapi ancaman membahayakan perekonomian Nasional dan atau Stabilitas Keuangan.

10 Mike Dionne, More Regional Banks May Merge to Meet Tech Challenges, AM. BANKER (https://www.americanbanker.com/opinion/regional-banks-must-merge-tomeet-tech-challenges [https://perma.cc/6ZNK-XA5W]. 23 Februari 2021

11 Jeremy C. Kress, Modernizing Bank Merger Review, 37 YALE J. ON Reg. (2020). Available at: https://digitalcommons.law.yale.edu/yjreg/vol37/iss2/2 23 Februari 2021

${ }^{12}$ Muhammad Afdi Nizar \& Mohamad Nasir, Strengthening Sharia Banking through Merger or Consolidation, Acceleration and Inclusiveness of the Financial Sector: Pathway to People's Welfare", Naga Media (2016) with the same title Online at https://mpra.ub.uni-muenchen.de/97964/ MPRA Paper No. 97964, posted 05 Jan 2020, 623 Februari 2021 
Berdasarkan penjelasan di atas, dapat diketahui permasalahan dalam penelitian ini yaitu bagaimana pengaturan atas merger bank syariah BUMN menjadi bank syariah Indonesia dan bagaimana dampak hukum merger bank syariah Indonesia terhadap stabilitas kebijakan ekonomi negara?

\section{B. Metode Penelitian}

Metode penelitian yang digunakan dalam penelitian ini menggunakan penelitian normatif dengan pendekatan perundang-undangan dan pendekatan konseptual. ${ }^{13}$ Sumber hukum primer menggunakan peraturan hukum terkait merger lembaga perbankan dan sumber hukum sekunder dari beberapa literatur seperti jurnal dan buku berkaitan dengan permasalahan yang sedang di bahas. Sedangkan teknik analisis bahan hukum menggunakan deskriptif. ${ }^{14}$

\section{Hasil Temuan dan Pembahasan}

\section{Penguatan Merger Bank Syariah dalam Akad Kerja sama}

Merger adalah gabungan dari dua atau lebih perusahaan menjadi satu perusahaan tempat seseorang bertahan hidup dan yang lainnya kehilangan keberadaan korporasinya. Sejak tahun 1991 sektor perbankan telah mengalami proses transformasi dan konsolidasi. Merger adalah skenario yang berulang kali terjadi di seluruh dunia. Kemajuan teknologi, peluang yang muncul, kapasitas retensi berlebih dan deregulasi lingkungan, peningkatan skala ekonomi, tingkat stok, pembelian saham baru dan peningkatan tingkat ekonomi bank anak perusahaan, persetujuan layanan pelanggan, dll. Adalah alasan dasar untuk merger. Untuk mengadopsi lingkungan yang cepat berubah, sektor perbankan sedang dalam proses konsolidasi, restrukturisasi dan penguatan perusahaan agar terus kompeten dan berkelanjutan. Berbagai literatur dikaji untuk membahas berbagai alasan merger.

Dalam ekonomi globalisasi saat ini, merger semakin banyak digunakan di seluruh dunia meningkatkan daya saing perusahaan melalui perolehan pangsa pasar yang lebih besar, memperluas portofolio untuk mengurangi risiko bisnis, untuk memasuki pasar dan geografi baru, dan memanfaatkan skala ekonomi, dll. Merger adalah kombinasi dari dua atau lebih entitas melalui akuisisi pembelian atau penyatuan kepentingan, itu berbeda dari konsolidasi karena tidak ada entitas baru yang dibuat dari merger. Motif di balik merger adalah skala ekonomi, cakupan ekonomi, peningkatan pangsa pasar dan pendapatan, perpajakan, sinergi, geografis dan diversifikasi lainnya. Oleh karena itu bank-bank melakukan merger atau menjadi

${ }^{13}$ I Made Pasek Diantha, Metodologi Penelitian Hukum Normatif dalam Justifikasi Teori Hukum, Jakarta, Kencana, 2016, hlm. 156

${ }^{14}$ I Made Pasek Diantha, Metodologi Penelitian Hukum Normatif dalam Justifikasi Teori Hukum, Jakarta, Kencana, 2016, hlm. 152 
target akuisisi bank. Sektor keuangan telah menjadi fokus baik di kalangan bisnis maupun di media, dalam hal tantangan luar biasa yang sedang dihadapi. ${ }^{15}$

McClure, (2010) merekomendasikan bahwa Merger dan akuisisi adalah bagian penting dari kemajuan dan pertumbuhan industri perbankan. Dua perusahaan bersama-sama lebih berharga daripada dua perusahaan terpisah, ini mungkin salah satu alasan di balik merger dan akuisisi. Yelena V. Smirnova (2015) menyatakan pemahaman yang lebih dalam tentang motif merger dan akuisisi memungkinkan kita untuk mengenali kekuatan apa (ekonomi, keuangan, teknologi, dll.) Yang mendorong perusahaan dan perusahaan lain menuju penciptaan aliansi semacam itu. KomalGupta (Maret 2015) mengatakan bahwa sektor perbankan memainkan peran penting pertumbuhan dan perkembangan ekonomi suatu bangsa. Deregulasi, Globalisasi ekonomi ditambah dengan perkembangan teknologi telah mengubah lanskap Sektor perbankan secara dramatis. Untuk menghadapi perubahan lingkungan, perbankan menempuh proses konsolidasi, restrukturisasi dan penguatan korporasi agar tetap efisien dan layak. ${ }^{16}$

Dalam Bahasa Indonesia, merger disebut dengan penggabungan perusahaan, yaitu suatu proses hukum untuk meleburnya perusahaan yang kurang maksimal kinerjanya ke dalam perusahaan lainnya yang dapat menunjukkan kinerja maksimal baik, sehingga menyebabkan perusahaan yang meleburkan diri tersebut menjadi bubar. ${ }^{17}$ Peraturan Pemerintah Republik Indonesia No.57/2010 menyatakan penggabungan diartikan sebagai suatu perbuatan hukum yang dilakukan oleh badan usaha satau atau lebih dengan menggabungkan diri bersama badan usaha lainnya dengan saling menggabungkan diri karena hukum. Sedangkan OJK mengatur definisi merger dalam POJK No.74/POJK.04/2016 bahwa penggabungan (merger) suatu perbuatan hukum yang dilakukan oleh satu perusahaan atau lebih menggabungkan diri dengan perusahaan lain yang sudah ada berakibat pada aset, liabilitas, dan ekuitas dari perusahaan yang mergerkan diri beralih karena hukum kepada perusahaan yang menerima penggabungan dan kemudian berstatus badan hukum perusahaan merger berakhir karena hukum.

Menurut Anthony ${ }^{18}$, merger mengacu pada kombinasi dua atau lebih organisasi menjadi satu organisasi yang lebih besar. Tindakan semacam itu biasanya bersifat sukarela dan sering kali berakibat nama organisasi baru (sering kali

15 Muhammad Usman Kemal, Post-Merger Profitability: A Case of Royal Bank of Scotland (RBS), International Journal of Business and Social Science Vol. 2 No. 5; [Special Issue -March 2011] 157 https://ijbssnet.com/journals/Vol._2_No._5_[Special_Issue_-_March_2011]/20.pdf 24 Februari 2021

16 Sarika and Vasantha, Motives and Drivers of the Bank Merger, International Journal of Pure and Applied Mathematics Volume 118 No. 5 2018, 167-174 ISSN: 1311-8080 (printed version); ISSN: 1314-3395 (on-line version) url: http://www.ijpam.eu Special Issue, https://acadpubl.eu/jsi/2018-1185/articles/5/12.pdf ,168 24 Februari 2021

17 Toman Sony Tambunan \& Wilson R.G. Tambunan, Hukum Bisnis, Jakarta, Kencana, 2019, hlm.

18 Asauten Samuila, The Effects of Mergers and Acquisitions on The Performance of Commercial Banks In Nigeria : Evidenced from United Bank for Africa (UBA) pls by Anderibom, International Journal of Education and Research Vol. 3 No. 4 April 2015 https:/www.ijern.com/journal/2015/April-2015/10.pdf 23 Februari 2021 
menggabungkan nama organisasi asli). Sebuah akuisisi, di sisi lain, adalah pembelian satu organisasi oleh organisasi lain. Tindakan semacam itu bisa jadi bermusuhan atau bersahabat dan pihak pengakuisisi memegang kendali atas perusahaan yang diakuisisi. Kepada Umar merger adalah transaksi yang melibatkan dua atau lebih perusahaan di mana saham dipertukarkan tetapi di dalamnya yang hanya bertahan satu perusahaan. Merger biasanya terjadi antara perusahaan dengan ukuran yang agak mirip dan biasanya ramah. Perusahaan yang dihasilkan kemungkinan besar memiliki nama yang berasal dari kompositnya perusahaan, sedangkan akuisisi adalah pembelian perusahaan yang sepenuhnya diserap sebagai operasi anak perusahaan atau divisi dari perusahaan yang mengakuisisi. Melihat merger dan akuisisi sebagai istilah bisnis global yang digunakan dalam mencapai pertumbuhan dan kelangsungan hidup bisnis. Penggabungan memerlukan datang bersama-sama dari dua atau lebih firma untuk menjadi satu firma besar sementara akuisisi mengambil alih atau pembelian perusahaan kecil oleh perusahaan besar, keduanya mengejar motif serupa Oleh karena itu, merger dapat dilihat sebagai kombinasi atau penggabungan dari dua atau lebih pisahkan perusahaan menjadi satu perusahaan di mana yang satu bertahan dan yang lainnya kehilangan korporasinya eksistensi sementara akuisisi dapat dilihat sebagai pengambilalihan kepentingan pemegang saham pengendali dari perusahaan lain. Biasanya, di akhir proses, ada dua entitas atau perusahaan. Perusahaan target menjadi divisi atau anak perusahaan dari perusahaan yang mengakuisisi. Menurut Ransariya, merger dapat diartikan sebagai singkatan yang artinya:
M: Pencampuran
E: Entitas
R: Sumber daya untuk
G: Pertumbuhan
E: Pengayaan dan
R: Renovasi ${ }^{19}$

Dengan demikian, seseorang dapat dengan mudah menyebut merger sebagai pencampuran sumber daya entitas untuk pertumbuhan dan renovasi.

Ada beberapa bentuk merger yang dapat diketahui, yaitu: a. Horizontal merger, artinya merger dapat terlaksana manakala dua atau lebih perusahaan yang bergerak di bidang yang sama. Bentuk merger ini, berakibat perluasan operasi perusahaan ke lini produk tertentu dan di waktu yang sama bisa mengurangi pesaing, b. Vertikal merger, yaitu merger dapat terjadi manakala perusahaan melakukan akuisisi perusahaan supplier, semisal perusahaan rokok akuisisi perusahaan perkebunan tembakau, perusahaan garmen akuisisi perusahan tekstil, dan seterusnya. Akibat dari merger tentu saja memberikan manfaat ekonomi vertikal merger terhadap

19 Asauten Samuila, The Effects of Mergers and Acquisitions on The Performance of Commercial Banks In Nigeria: Evidenced from United Bank for Africa (UBA) pls by Anderibom, International Journal of Education and Research Vol. 3 No. 4 April 2015 https:/www.ijern.com/journal/2015/April-2015/10.pdf 23 Februari 2021 
peningkatan dari pengaturan kontrol perusahaan terhadap bahan baku atau distribusi barang akhir perusahaan yang diakuisisi, c. Conglomerate merger, merupakan merger yang terjadi antara perusahaan yang tidak saling terkait. Contohnya, merger perusahaan penghasil food products dengan perusahaan komputer. Manfaatnya adalah mampu mengurangi risiko karena perusahaan bergabung memiliki pola skilikal dan penjual musiman serta pendapatan yang berbeda. ${ }^{20}$ Definisi merger juga diatur dalam PMK RI No.84/PMK.012/2006 bahwa merger adalah penggabungan dari dua perusahaan pembiayaan atau lebih dengan cara tetap mempertahankan berdirinya salah satu perusahaan dan membubarkan perusahaan lainnya dengan atau tanpa likuidasi. Merger dapat diartikan sebagai serikat bisnis, sehingga tercapai kepemilikan bersama. Penggabungan dapat berupa penggabungan horizontal dan penggabungan vertikal. Strategi merger antar unit usaha syariah dapat dimasukkan dalam kategori merger horizontal.

Merger dilakukan atas kesepakatan dua atau lebih perusahaan yang bergabung menjadi satu perusahaan tetap ada sebagai badan hukum, sementara yang lainnya menghentikan aktivitasnya atau bahkan bubar. ${ }^{21}$ Sinergi perusahaan sebagai akibat dari merger tentu saja akan memberikan penghematan operasi sehingga menghasilkan skala ekonomis manajemen, marketing, produksi atau distribusi. Kemudian, penghematan keuangan menjadi hal kedua yang memengaruhi merger perusahaan yaitu biaya transaksi lebih rendah dan evaluasi menjadi lebih baik oleh analisis sekuritas. Perbedaan efisiensi, menjadi penentu dalam merger, artinya lebih produktif, dan yang terakhir pasar dapat dikuasai secara meningkat dan persaingan menjadi berkurang. Dampak dari keputusan merger menjadi penentu perbaikan kondisi dan kinerja perusahaan, dengan bergabungnya dua atau lebih perusahaan tentunya meningkatkan kegiatan usaha, sehingga deviden yang dihasilkan menjadi lebih besar dibandingkan jika perusahaan masih sendiri. Keuntungan yang besar tersebut dapat memberikan kekuatan terhadap keuangan perusahaan melakukan merger.

Merger sendiri bisa terjadi karena adanya sepakat yang tertuang dalam akad kerja sama. Transaksi kerja sama antar perusahaan ini membutuhkan perjanjian. Perjanjian atau kontrak merupakan bagian penting yang mengalami perkembangan dalam rangka memberikan kepastian bidang ekonomi dan stabilitas nasional. ${ }^{22} \mathrm{Hukum}$ perjanjian atau kontrak masih menggunakan peraturan pemerintah colonial Belanda yang terdapat dalam Buku III KUHPerdata. Buku III KUHPerdata menganut sistem terbuka yang artinya para pihak bebas mengadakan kontrak dengan siapapun, menentukan syarat-syaratnya, pelaksanaannya, dan bentuk kontrak baik berbentuk lisan maupun tertulis. Di samping itu, diperbolehkan membuat kontrak baik yang dikenal dalam KUHPerdata maupun diluar KUHPerdata. Pertumbuhan dan

${ }^{20}$ Gitman, L. J. and Zutter, C.J, (Principles of managerial finance. 13th Edition. Boston: Prentice Hall, 2012

${ }^{21}$ Lisa Laiman dan Saarce Elsye Hatane, Analisis Dampak Merger dan Akuisisi Terhadap Kinerja Keuangan pada Perusahaan Non Keuangan Yang Terdaftar di Bursa Efek Indonesia Periode Tahun 20072014, Business Accounting Review, Vol. 5 No. 2, 2017, http://publication.petra.ac.id/index.php/akuntansibisnis/article/view/6629 23 Februari 2021

22 Syahmin AK, Hukum Kontrak Internasional, Jakarta, PT. Rajagrafindo Persada, 2006, hlm. 17 
perkembangan prinsip dan bentuk dari perjanjian tidak terlepas dari beberapa faktor, diantaranya faktor intern, faktor ekstern, dan faktor meningkatnya frekuensi dan aneka macam serta bentuk kegiatan bisnis. ${ }^{23}$

Penggabungan bank bisa terlaksana dengan mematuhi setiap aturan hukum yang berlaku. Seperti yang dijelaskan di atas, diperlukan adanya perjanjian penggabungan Bank Umum Syariah. Hakikatnya perjanjian sangatlah krusial dan memberikan kontribusi besar hukumnya sebagai alat bukti. Merger tidak dapat terjadi tanpa adanya suatu perjanjian. Keharusan perjanjian diberlakukan terhadap merger 3 bank umum syariah, yang berakibat terjadinya perubahan anggaran dasar perusahaan dari hasil penggabungan perusahaan maupun sama sekali tidak mengakibatkan perubahan anggaran dasar perusahaan hasil merger tersebut. Perjanjian adalah dokumen penting yang bisa dikatakan fondasi sekaligus pilar yang menghubungkan antara satu pihak dengan pihak lain. Kedua, diperlukan persetujuan rapat umum pemegang saham (RUPS). Persetujuan RUPS mutlak dan harus ada dalam proses penggabungan. Hal ini diatur dalam bab III Penyelenggaraan RUPS dalam rangka Penggabungan Usaha atau Peleburan Usaha pasal 17(1) dan (2) POJK No.74/POJK.04/2016. Penggabungan Bank Umum Syariah ini merupakan perusahaan terbuka, artinya bahwa segala ketentuan merger tersebut memerlukan persetujuan sehingga terbentuk penguatan merger bank syariah. Selain itu direksi perusahaan terbuka yang hendak merger wajib mendapatkan pernyataan dari OJK dan RUPS guna memperhatikan kepentingan bersama (perusahaan, masyarakat, dan persaingan sehat usaha, serta menjamin agar tetap terpenuhi hak daripada pemegang saham dan juga karyawan). Hal ini sebagaimana diatur dalam pasal 5 POJK tentang Penggabungan Usaha atau Peleburan Usaha Perusahaan Terbuka No.74/POJK.04/2016. Legal due diligence, hal ini sangat diperlukan guna mengetahui hak dan kewajiban serta litigasi juga permasalahan hukum yang dihadapi bank, menjadi fondasi legal opinion dari para penasihat hukum. Kemudian, memberitahukan rencana dan hasil dari merger, selanjutnya mengajukan permohonan persetujuan kepada kementerian Hukum dan HAM dan OJK. Akibat merger, tentu saja muncul permasalahan hukum perpajakan, masalah persaingan usaha mengatur tentang hasil merger tidak melebihi dari 20 persen dari total aset perbankan nasional, dan permasalahan beralihnya hak, kewajiban, perkara, dan permasalahan hukum lainnya kepada bank atas hasil merger. ${ }^{24}$

Ada beberapa alasan mengapa merger dapat dilakukan oleh sejumlah perusahaan, yaitu pertumbuhan atau diversifikasi, yang mana perusahaan mengharapkan pertumbuhan yang cepat baik dari ukuran, pasar saham, hingga diversifikasi usaha ketimbang mendirikan usaha sendiri. Di samping itu, perusahaan juga tidak memiliki risiko terhadap produk baru, artinya tetap menjalankan produk yang sudah ada dan dikembangkan secara bersamaan berdasarkan kesepakatan

${ }^{23}$ Syahmin AK, Hukum Kontrak Internasional, Jakarta, PT. Rajagrafindo Persada, 2006, hlm.36-37

${ }^{24}$ Muhammad Afdi Nizar \& Mohamad Nasir, Strengthening Sharia Banking through Merger or Consolidation, Acceleration and Inclusiveness of the Financial Sector: Pathway to People's Welfare", Naga Media (2016) with the same title Online at https:/mpra.ub.uni-muenchen.de/97964/ MPRA Paper No. 97964, posted 05 Jan 2020, 3624 Februari 2021 
bersama. Dengan melakukan merger, penguatan perusahaan menjadi meningkat dengan berkurangnya pesaing antar perusahaan yang sama sehingga dapat menaikkan harga produk bagi pembeli atau menurunkan harga bahan baku yang dibayarkan kepada pemasok. ${ }^{25}$ Faktor yang paling mendasar dari merger adalah motif ekonomi. Di sisi lain, merger perusahaan yang dibenarkan manakala menguntungkan. Keadaan yang saling menguntungkan disini dapat terjadi apabila dari terlaksananya merger diperoleh suatu sinergi, sinergi yang bernilai gabungan antar perusahaan yang sepakat merger lebih besar keuntungannya daripada perusahaan yang terpisah. ${ }^{26}$

Percepatan pembangunan Indonesia, tentunya ditandai dengan semakin banyaknya para pemodal berinvestasi dan mendirikan perusahaan secara terikat dalam sebuah kesepakatan tertulis yang dikenal dengan perjanjian standar. Penggunaan perjanjian standar dapat secara efektif dan efisien memperkecil kemungkinan terjadinya risiko, secara perlahan diikuti oleh perusahaan-perusahaan dalam negeri baik berskala besar, sedang, dan kecil. Dengan demikian, berkembangnya paham negara kesejahteraan (welfare state) menyebabkan semakin besarnya keterlibatan negara dalam mengatur dan mengelola perlbagai kehidupan masyarakat, yang awalnya diatur dan dikelola oleh masyarakat sendiri. Muncul pelbagai peraturan yang dikeluarkan oleh pemerintah Indonesia, seperti yang terkait dengan penggabungan perusahaan bank syariah.

Penggabungan beberapa unit usaha syariah akan mampu memperkuat permodalan bank syariah hasil merger. ${ }^{27}$ Selain itu, penggabungan antar unit usaha syariah akan membuat mereka lebih siap bersaing dalam komunitas ekonomi ASEAN. ${ }^{28}$ Menteri Perencanaan Pembangunan Nasional/Kepala Bappenas menyatakan ada perdagangan, keuangan, dan geopolitik risiko, menempatkan negara pada risiko ketidakstabilan dan kerentanan. Dengan tidak adanya ketidakpastian eksternal, peluang, dan transformasi adalah kunci perekonomian nasional. Mempertimbangkan dan menganalisis global kondisi di atas, menggabungkan ketiga anak perusahaan Bank Umum Syariah BUMN telah menemukan momentum yang tepat dan strategis. Indonesia harus merencanakan dan melaksanakan pengeluaran ekonomi syariah global pasar sebesar USD 2,02 triliun dengan baik dan ditargetkan untuk meningkat setelah era pandemi Covid-19. Ini menjanjikan peluang untuk menggerakkan

${ }^{25}$ Erik Devos, Palani-Rajan Kadapakkam, Srinivasan Krishnamurthy, How Do Mergers Create Value? A Comparison of Taxes, Market Power, and Efficiency Improvements as Explanations for Synergies, The Review of Financial Studies, Volume 22, Issue 3, March 2009, Pages 11791211, https://doi.org/10.1093/rfs/hhn019 24 Februari 2021

${ }^{26}$ DePamphilips, D. (2011). Mergers and acquisitions basics: All you need to know. Kidlington : Elsevier Inc https://www.elsevier.com/books/mergers-and-acquisitions-basics/depamphilis/978-0-12374948-2 24 Februari 2021

${ }^{27}$ Khulifa Ahdizia, Dian Masyita, \& Sutisna. (2018). Business Valuation of Islamic Banks in the Merger Plan to Become Indonesia's State-Owned Bank. Jurnal Etikonomi , Vol. 17(2), 223 http://journal.uinjkt.ac.id/index.php/etikonomi/article/view/7238, Doi : 10.15408/etk.v17i2.7238 24 Februari 2021

${ }^{28}$ Qamar Abbas, Ahmed Imran Hunjra, Rauf I Azam, Muhammad Shahzad Ijaz, \& Maliha Zahid. (2014). Financial Performance of Banks in Pakistan After Merger and Acquisition. Journal of Global Entrepreneurship Research, Vol 4(13), 1 https://journal-jger.springeropen.com/articles/10.1186/s40497-0140013-4 24 Februari2021 
perekonomian nasional. Bank syariah produk dan jasa pembiayaan kepada sektor riil, khususnya sektor ekonomi halal yang lebih masif, dibutuhkan, baik pada skala perusahaan (grosir), komersial, konsumen, dan UMKM. Visi menjadikan Indonesia syariah terdepan ekonomi di dunia realistis dalam hal geostrategi. Indonesia memiliki sumber modal yang kuat. Indonesia adalah bagian dari komunitas global, dan satusatunya negara di Asia Tenggara termasuk dalam kelompok negara anggota G-20. Kelompok ini mengumpulkan hampir 90\% dari produk nasional bruto dunia (GNP, GNP), 80\% dari total perdagangan dunia, dan dua pertiga darinya populasi. Artinya Indonesia memberikan kontribusi yang besar pesanan produk domestik bruto (PDB) dunia. Berpartisipasi dalam Forum G-20 telah membuat Indonesia harus berkreasi internasional standar dan komitmen, yang tetap tak terkalahkan ketahanan nasional. ${ }^{29}$

\section{Dampak Merger Bank Syariah Terhadap Stabilitas Ekonomi Negara}

Dinamika kegiatan terselenggaranya kekuasaan negara yang dimulai dari terbentuknya norma hukum guna melakukan pengawasan atau pengontrolan dilakukan dengan beberapa cara atau mekanisme. Menurut Jimly Ashshiddiqie, ada tiga cara untuk mengendalikan norma hukum, yaitu upaya hukum, upaya politik, dan upaya administrasi. ${ }^{30}$ Salah satu masalah serius yang sedang dihadapi pembangunan ekonomi Indonesia ialah mempraktikkan kerangka hukum dan konstitusi dalam pengembangan kebijakan-kebijakan perekonomian. Seperti diketahui bahwa konstitusi menjadi kebijakan tertinggi yang memerlukan kegesitan dan keluwesan dari perubahan - perubahan dinamis yang terjadi pada sektor pasar ekonomi secara global, nasional, dan lokal yang terus bergerak setiap hari secara cepat.

Perlu dipahami, bahwa UUD 1945 merupakan kebijakan ekonomi tertinggi sebagai konstitusi ekonomi yang wajib dijadikan sebagai landasan dan rujukan guna pengembangan pembangunan ekonomi nasional. Kebijakan ekonomi tersebut bersifat memaksa yang dituangkan dalam bentuk perundang-undangan serta peraturan pelaksanaannya. Semua peraturan yang dibuat tidak boleh bertentangan dengan peraturan yang lebih tinggi. Artinya, undang-undang tidak boleh bertentangan dengan UUD 1945.

Di era modern seperti sekarang ini, pembaruan hukum, baik dalam arti pembaruan peraturan perundang-undangan dan pembaruan kelembagaan hukum maupun pembaruan budaya hukum, merupakan pilar yang penting di antara tiga agenda utama reformasi, yaitu pembaruan hukum (legal reform), demokrasi (democracy), dan liberalisasi ekonomi (economic liberalization). Dengan demikian, hukum tidak dapat berkembang tanpa dukungan ekonomi yang tumbuh. Namun perekonomian tidak akan tumbuh dan berkembang jika hukum tidak mampu

${ }^{29}$ Agus Hartanto \& Nur Fatwa, The Geostrategy of Sharia Banking Merger in Indonesia, Scientific Research Journal (SCIRJ), Volume VIII, Issue XII, December 2020 ISSN 2201-2796 DOI: 10.31364/SCIRJ/v8.i12.2020.P1220829 http://dx.doi.org/10.31364/SCIRJ/v8.i12.2020.P1220829,63 24 Februari 2021

\footnotetext{
${ }^{30}$ Jimly Asshiddiqie, Konstitusi Ekonomi, Jakarta, Penerbit Buku Kompas, 2010, hlm. 7
} 
menjamin keadilan yang pasti dan kepastian yang adil. Kegiatan perekonomian tidak akan berkembang pesat, bila tidak diimbangi dengan stabilitas politik dan derajat kebebasan yang teratur. Oleh karena itu, hukum dapat difungsikan dan berfungsi sebagai penggerak dan pengarah guna mencapai tujuan-tujuan suatu masyarakat di bidang perekonomian. Artinya, hukum dapat berfungsi sebagai sarana pembaruan masyarakat (tool of social engineering).

Pelaksanaan merger telah diatur di beberapa aturan hukum yang dibuat oleh negara sebagai bentuk perlindungan hukum secara pasti dan adil, sehingga stabilitas ekonomi negara terjamin. Stabilitas ekonomi menjadi lebih baik dikarenakan adanya penguatan di sektor keuangan guna mendorong kegiatan ekonomi tumbuh secara cepat. Peningkatan kinerja sekaligus kesinambungan di sektor keuangan dari pendanaan pembangunan, kebijakan sektor keuangan difokuskan pada upaya menjaga ketahanan indistri di sektor jasa keuangan, peningkatan fungsi intermediasi dana masyarakat, serta pengembangan sistem jaring dari pengamanan di sektor keuangan.

Securities and Exchange Commission Quarterly, mengungkapkan bahwa sebagian besar bank melakukan merger. Namun, ada berbagai alasan mengapa bank memilih merger. Alasan tersebut antara lain: untuk mendapatkan ekonomi operasi dengan menghilangkan duplikasi dan persaingan tidak sehat, untuk memperoleh manajemen yang agresif dan kompeten, untuk mendiversifikasi dan meningkatkan kualitas pendapatan dan untuk mencari pertumbuhan yang cepat, meningkatkan likuiditas dan stabilitas keuangan bank. Menurut Anthony, ada banyak dan beragam alasan pembeli ingin mengakuisisi perusahaan lain. Ini alasannya mungkin termasuk: untuk memasuki pasar yang lebih menguntungkan, untuk mendiversifikasi atau memperluas produknya dan untuk menghindari biaya memulai bisnis, lapangan atau industri baru. Di sisi lain, penjual mungkin ingin, antara lain, diakuisisi untuk dapat memperoleh pembiayaan baru atau tambahan, atau memenuhi kebutuhan aset likuiditas pemiliknya seperti sekuritas yang dapat diperjualbelikan dari pihak pengakuisisi. $^{31}$

Dari kacamata analisis bisnis, ada beberapa pertimbangan terkait merger bank syariah yaitu, bank syariah mampu bersaing secara sehat dengan bank-bank konvensional disebabkan tidak ada lagi pengendalian dari bank konvensional sebagai induk perusahaan, bank syariah juga mampu meningkatkan pelayanan jasa keuangan yang diberikan kepada para stakeholder. Hal ini bersamaan dengan peningkatan modal inti, sehingga dapat bersaing dengan bank konvensional. ${ }^{32}$

Sejak pandemi melanda negara Indonesia, laju pertumbuhan ekonomi nasional terhambat, penerimaan negara menjadi menurun, namun belanja negara dan pembiayaan meningkat, sehingga salah satu upaya pemerintah untuk menyelamatkan

${ }^{31}$ Anderibom Asauten Samuila \& Obute, Christopher O, The Effects of Mergers and Acquisitions on The Performance of Commercial Banks in Nigeria: Evidenced from United Bank for Africa (UBA) plc, ISSN: 24115681 International Journal of Education and Research Vol. 3 No. 4 April 2015 www.ijern.com, https://www.ijern.com/journal/2015/April-2015/10.pdf, 10024 Februari 2021

32 Strengthening Sharia Banking through Merger or Consolidation Nizar, Muhammad Afdi Online at https://mpra.ub.uni-muenchen.de/97964/ MPRA Paper No. 97964, posted 05 Jan 2020, 24 Februari 2021 
perekonomian negara dimulai dengan memberikan sejumlah kebijakan yang mampu memberikan sumbangsih peningkatan ekonomi bagi pendapatan negara yang diterbitkan dalam Perpu No.1/2020. ${ }^{33}$ Dengan demikian, penggabungan merger 3 bank syariah yang sekarang bernama Bank Syariah Indonesia menjadi salah satu terobosan positif guna meningkatkan pendapatan ekonomi negara. OJK sebagai lembaga yang memiliki sistem pengawasan sebagaimana diatur dalam UU Otoritas Jasa Keuangan, memiliki kewenangan untuk menerbitkan aturan khusus terkait merger bank berbasis syariah, sehingga kegiatan perekonomian dapat berjalan sebagaimana mestinya.

Belum ada definisi baku yang bisa diterima secara Internasional tentang stabilisasi sistem keuangan. Namun ada beberapa definisi terkait stabilitas sistem keuangan yang pada intinya bahwa suatu sistem keuangan telah masuk ke tahap ketidak stabilan atas sistem tersebut yang dapat membahayakan dan menghambat kegiatan ekonomi. Stabilitas sistem keuangan dapat kita pahami dengan melakukan riset terhadap faktor-faktor yang dapat menyebabkan instabilitas di sektor keuangan. Dari ketidak stabilan tersebut menyebabkan berbagai macam gejolak. Hal ini dikarenakan adanya perpaduan kegagalan pasar, baik struktural maupun perilaku. Gagal pasar bisa terjadi dari eksternal (Internasional) maupun internal (domestik). Oleh karena itu, risiko yang sering menghambat sistem keuangan diantaranya risiko kredit, risiko likuiditas, risiko pasar dan risiko operasional. ${ }^{34}$

Merger di sektor keuangan sebagian besar merupakan hasil dari destabilisasi dalam lingkungan persaingan untuk jasa keuangan, yang disebabkan oleh deregulasi nasional pasar dan peningkatan metode baru dalam menangani pelanggan. Secara khusus, pertumbuhan jaringan elektronik membuka pasar jasa keuangan kepada semakin banyak pesaing, yang tidak lagi bergantung pada jaringan cabang tradisional untuk menarik bea cukai. Secara keseluruhan, sulit untuk menilai dampak merger dan akuisisi terhadap konsumen, tidak hanya karena aspek ini biasanya tidak dipertimbangkan dalam analisis populer atau ilmiah, tetapi juga karena seringkali sulit untuk menguraikan dampak langsung merger dari pengaruh faktor-faktor lain seperti meningkatnya persaingan global atau perubahan teknologi. Melihat dampak merger terhadap penyediaan produk, pilihan, dan biaya produk, dikatakan bahwa secara umum, jumlah produk di pasar telah meningkat secara signifikan dalam beberapa tahun terakhir, menawarkan lebih banyak pilihan dengan harga yang lebih murah, karena sebagian besar pendatang baru di pasar berusaha bersaing atas dasar harga. Mereka dapat melakukan ini karena teknologi informasi dan komunikasi baru memungkinkan mereka menghemat biaya dengan beroperasi dengan lebih sedikit cabang atau tanpa jaringan cabang tradisional. Produk dan penyedia baru juga dianggap menawarkan lebih banyak fleksibilitas waktu kepada klien, karena mereka

${ }^{33}$ Sekretariat Kabinet Republik Indonesia, Isi Perpu Kebijakan Keuangan Negara dan Stabilitas Sistem Keuangan Hadapi Covid-19, 2020

https://setkab.go.id/isi-perpu-kebijakan-keuangan-negara-dan-stabilitas-sistem-keuangan-hadapi-covid19/ 24 Februari 2021

${ }^{34}$ Otoritas Jasa Keuangan, Definisi Stabilitas Sistem Keuangan,

https://www.ojk.go.id/id/kanal/perbankan/stabilitas-sistem-keuangan/Pages/Ikhtisar.aspx 24 Februari 2021 
tidak lagi harus bergantung pada jam buka cabang untuk menjalankan bisnis mereka. Penyedia tradisional telah menanggapi tren ini -untuk memenuhi kebutuhan konsumen, tetapi juga untuk memotong biaya operasional- dengan menutup cabang. ${ }^{35}$

Seperti halnya di Eropa, ada alasan kuat untuk menyatakan bahwa merger di industri jasa keuangan Eropa lebih baik dipandang sebagai konsekuensi, daripada sebagai penyebab langsung, dari perubahan kompetitif dalam industri jasa keuangan Eropa. Dengan kata lain, pertumbuhan aktivitas merger dan take over dapat diartikan sebagai akibat dari ketidakstabilan lingkungan persaingan jasa keuangan selama 25 hingga 30 tahun terakhir. Pasar jasa keuangan menjadi lebih kompetitif selama periode ini, setidaknya karena dua alasan. Pertama, putaran-putaran regulasi ulang nasional dan Eropa yang berturut-turut telah menghilangkan hambatan regulasi "structural" yang sebelumnya membuat perusahaan terkurung di bagian sempit dari sistem keuangan, dan yang telah mendorong perusahaan untuk berekspansi ke pasar keuangan baru sehingga meningkatkan tingkat persaingan. di dalam diri mereka. Kedua, putaran inovasi keuangan yang berturut-turut juga telah meningkatkan tingkat persaingan, yang telah mengubah dasar di mana perusahaan bersaing satu sama lain untuk mendapatkan pelanggan dan pangsa pasar. Mungkin contoh terbaik dari hal ini adalah pertumbuhan database elektronik sebagai alat untuk menyortir dan mengelola pelanggan. Penggunaan database relasional yang dikombinasikan dengan penilaian kredit otomatis dan sistem pemasaran "forensik"telah mengurangi ketergantungan perusahaan jasa keuangan yang sudah mapan pada jaringan cabang tradisional mereka, yang merupakan cara yang mahal untuk mendistribusikan produk dan layanan kepada pelanggan. ${ }^{36}$

Pemerintah melalui Menteri keuangan mengeluarkan kebijakan dalam Peraturan Menteri Keuangan No.52/PMK.010/2017 mengganti PMK No.43/PMK.03/2008 tentang Penggabungan Nilai Buku atas Pengalihan Harta dalam Rangka Penggabungan, Peleburan, Pemekaran, atau Pengambilalihan Usaha, memberikan dampak daripada merger salah satunya tentang pajak. Bank Syariah Indonesia merupakan perusahaan yang sudah go public, dikenal dengan istilah terbuka (Tbk). Merger bank syariah yang terdiri dari bank syariah mandiri, bank BNI syariah, bank BRI syariah, sebagai wajib pajak tidak memiliki sisa kerugian atau memiliki sisa kerugian lebih kecil diantara salah satu badan usaha yang mana modalnya terbagi atas saham dengan tetap mempertahankannya. Kewajiban pajak badan usaha meskipun 3 bank syariah bergabung menjadi satu badan usaha, tetap dikenakan membayar pajak yang diatur dalam beberapa pasal PMK No.52/PMK.010/2017. Pasal 1 (3a) menjelaskan bahwa penggabungan dua atau lebih wajib pajak badan hukum yang berdomisili di Indonesia, yang mana modalnya terbagi atas saham dapat mengalihkan seluruh harta dan berkewajiban terhadap salah satu

35 The Impact of Mergers and Acquisitions in the Banking and Insurance Sector, http://library.fes.de/pdf-files/netzquelle/01546.pdf 24 Februari 2021

36 Andrew Leyshon, Financial services mergers and acquisitions: Consumer impacts, http://library.fes.de/pdf-files/netzquelle/01546.pdf 24 Februari 2021 
wajib pajak badan tidak memiliki sisa kerugian fiscal atau mempunyai sisa kerugian fiskal yang lebih kecil serta pembubaran wajib pajak badan dapat mengalihkan harta dan kewajibannya tersebut. Setelah wajib pajak melakukan penggabungan usaha mengalami peningkatan usaha hingga angsuran pajak penghasilan pasal 25 yang seharusnya meningkat, besarnya angsuran pajak penghasilan pasal 25 disesuaikan dengan jumlah angsuran PPh pasal 25 wajib pajak menerima harta setelah merger.

Pemerintah dalam hal ini telah memberikan instruksi sejumlah lembaga berwenang guna penanganan atas stabilitas keuangan negara guna mengatur, mengawasi, dan melindungi dalam perpu diantaranya Bank Indonesia, Lembaga Penjamin Simpanan, dan Otoritas Jasa Keuangan yang diatur pada bab III terkait kebijakan stabilitas sistem keuangan pasal 16 s.d pasal 23. Sebagai bentuk menjaga stabilitas sistem keuangan negara, OJK mengeluarkan peraturan tertulis untuk penanganan permasalahan bank yang dalam bentuk POJK No.18/POJK.03/2020 sebagaimana yang diatur dalam Perpu No.1/2020. OJK memiliki kewenangan dalam perintah tertulis kepada lembaga jasa keuangan untuk melakukan penggabungan, peleburan, pengambilalihan, integrasi dan atau konversi maupun menerima penggabungan, peleburan, pengambilalihan, integrasi dan atau konversi, tujuannya menjaga sistem keuangan stabil di tengah kondisi pandemi COVID-19 dan menghindari ancaman krisis ekonomi.

Dua kondisi yang telah disebutkan di atas menjadi pertimbangan OJK memberikan perintah dalam bentuk tertulis kepada bank untuk melakukan penggabungan badan usaha, diatur dalam Pasal 23 ayat (1) huruf a Peraturan Perpu No.1/2020. Ada hal yang tidak diikutsertakan dalam hal ini aktivitas konversi yang mana perbuatan mengubah izin usaha kantor cabang di luar negeri menjadi izin usaha bank umum dalam upaya penguatan struktur, ketahanan, dan daya saing industri perbankan nasional.

Penguatan atas merger bank syariah BUMN menjadi PT. Bank Syariah Indonesia, Tbk adalah langkah tepat dilakukan di tengah pandemi, agar keuangan negara tetap stabil dan 3 bank syariah tergabung dalam merger mendapatkan profit dan deviden, meskipun masih dalam masa transisi sejak diresmikan tanggal 01 Februari 2021/19 Jumadil Akhir 1442 H menjadikan sejarah bergabungnya BSM, BNI Syariah, BRI Syariah menjadi satu entitas yaitu Bank Syariah Indonesia (BSI). Merger dari ketiga Bank Syariah menghadirkan layanan yang lebih lengkap, jangkauan lebih luas, serta memiliki kapasitas permodalan lebih baik. Didukung sinergi dengan perusahaan induk (Mandiri, BNI, BRI) serta komitmen pemerintah melalui kementerian BUMN, Bank Syariah Indonesia didorong untuk dapat bersaing di tingkat global.

\section{Kesimpulan}

Penguatan merger bank syariah BUMN (BNI Syariah, BSM, BRI Syariah) menjadi Bank Syariah Indonesia dimulai dengan adanya kesepakatan yang dituangkan dalam bentuk tertulis perjanjian penggabungan bank umum syariah sebagaimana 
diatur dalam beberapa peraturan hukum yang berlaku. Penggabungan bank umum syariah di tengah pandemi, menjadi langkah tepat guna menjaga stabilitas ekonomi negara sebagaimana Perpu No.1/2020 dan POJK No.18/POJK.03/2020. Dampak dari penggabungan bank umum syariah, tentunya memberikan dampak positif, bank syariah Indonesia mampu bersaing secara global dengan mengedepankan layanan yang lebih lengkap, jangkauan menjadi lebih luas, dan permodalan menjadi lebih baik. Bagi negara, tentunya menjadi hal baik yang dapat dilakukan oleh kementerian BUMN, dengan menggagas merger 3 anak perusahaan milik negara berbasis syariah (BNI Syariah, BSM, BRI Syariah) melebur menjadi PT. Bank Syariah Indonesia, Tbk.

\section{Referensi}

Abbas, Qamar, Ahmed Imran Hunjra, Rauf I Azam, Muhammad Shahzad Ijaz, \& Maliha Zahid. (2014). Financial Performance of Banks in Pakistan After Merger and Acquisition. Journal of Global Entrepreneurship Research, Vol 4(13), 1 https://journal-jger.springeropen.com/articles/10.1186/s40497-014-0013-4

Afdi Nizar, Muhammad \& Nasir, Mohamad. (2016) Strengthening Sharia Banking through Merger or Consolidation, Acceleration and Inclusiveness of the Financial Sector: Pathway to People's Welfare", Naga Media with the same title Online at https://mpra.ub.uni-muenchen.de/97964/ MPRA Paper No. 97964, posted 05 Jan 2020, 6

Ahdizia, Khulifa., Dian Masyita, \& Sutisna. (2018). Business Valuation of Islamic Banks in the Merger Plan to Become Indonesia's State-Owned Bank. Jurnal Etikonomi, Vol.

$17(2)$, http://journal.uinjkt.ac.id/index.php/etikonomi/article/view/7238, Doi: 10.15408/etk.v17i2.7238

Agus Hartanto \& Nur Fatwa. (2020). The Geostrategy of Sharia Banking Merger in Indonesia, Scientific Research Journal (SCIRJ), Volume VIII, Issue XII, December 2020 ISSN 2201-2796 DOI: 10.31364/SCIRJ/v8.i12.2020.P1220829 http://dx.doi.org/10.31364/SCIRJ/v8.i12.2020.P1220829,63 24 February 2021

Aisyah. (2017). Perkembangan Perbankan Syariah di Inggris,http://www.ibecfebui.com/perkembangan-perbankan-syariah-di-inggris/

AK, Syahmin. (2006). Hukum Kontrak Internasional, Jakarta, PT. Rajagrafindo Persada.

Al Arif, M. Nur Rianto, dkk. (2020). The Alternative Strategies for Accelerating Islamic Banking Growth: Mergers, Spin-Offs, Acquisitions and Conversions, Jurnal AlUlum Vol. 20 No.1 (2020), https://doi.org/10.30603/au.v20i1.1171, p.25

Anderibom Asauten Samuila \& Obute, Christopher O. (2015). The Effects of Mergers and Acquisitions on The Performance of Commercial Banks in Nigeria : Evidenced from United Bank for Africa (UBA) plc, ISSN: 2411-5681 International Journal of Education and Research Vol. 3 No. 4 April 2015www.ijern.com, https://www.ijern.com/journal/2015/April-2015/10.pdf 
Asauten Samuila, The Effects of Mergers and Acquisitions on The Performance of Commercial Banks In Nigeria : Evidenced from United Bank for Africa (UBA) pls by Anderibom, International Journal of Education and Research Vol. 3 No. 4 April 2015 https://www.ijern.com/journal/2015/April-2015/10.pdf

Atikah, Ika. (2018) Peran Pemerintah Terhadap Proteksi Hak-Hak Konsumen dalam Transaksi Ekonomi Syariah. Prosiding Seminar Nasional Prodi Hukum Ekonomi Syariah Universitas Muhammadiyah Purwokerto, http://digital.library.ump.ac.id/17/ 23

Devos, Erik. (2009). Palani-Rajan Kadapakkam, Srinivasan Krishnamurthy, How Do Mergers Create Value? A Comparison of Taxes, Market Power, and Efficiency Improvements as Explanations for Synergies, The Review of Financial Studies, Volume 22, Issue 3, March 2009, Pages 11791211, https://doi.org/10.1093/rfs/hhn019

DePamphilips, D. (2011). Mergers and acquisitions basics: All you need to know. Kidlington: Elsevier Inc https://www.elsevier.com/books/mergers-andacquisitions-basics/depamphilis/978-0-12-374948-2

Diantha, I Made Pasek. (2016). Metodologi Penelitian Hukum Normatif dalam Justifikasi Teori Hukum, Jakarta, Kencana.

Dionne, Mike. More Regional Banks May Merge to Meet Tech Challenges, AM. BANKER (https://www.americanbanker.com/opinion/regional-banks-must-mergetomeet-tech-challenges [https://perma.cc/6ZNK-XA5W].

Gitman, L. J. and Zutter, C.J. (2012). (Principles of managerial finance. 13th Edition. Boston: Prentice Hall.

Kemal, Muhammad Usman. (2011). Post-Merger Profitability: A Case of Royal Bank of Scotland (RBS), International Journal of Business and Social Science Vol. 2 No. 5; $\begin{array}{llll}\text { [Special } & \text { Issue } & \text {-March } & \text { 2011] }\end{array}$ https://ijbssnet.com/journals/Vol._2_No._5_[Special_Issue__March_2011]/20.pdf

Khusairi, Halil. (2015). Hukum Perbankan Syariah, Al-Qishthu Volume 13, Nomor 1 2015 ISSN 1858-1099 http://jurnal.fs.iainkerinci.ac.id/index.php/alqisthu/article/viewFile/9/2

Kress, Jeremy C. (2020). Modernizing Bank Merger Review, 37 YALE J. ON REG. Available at: https://digitalcommons.law.yale.edu/yjreg/vol37/iss2/2

Laiman, Lisa dan Saarce Elsye Hatane. (2017). Analisis Dampak Merger dan Akuisisi Terhadap Kinerja Keuangan pada Perusahaan Non Keuangan Yang Terdaftar di Bursa Efek Indonesia Periode Tahun 2007-2014, Business Accounting Review, Vol. 5 No. 2, 2017,http://publication.petra.ac.id/index.php/akuntansibisnis/article/view/6629

Leyshon, Andrew. Financial services mergers and acquisitions: Consumer impacts, http://library.fes.de/pdf-files/netzquelle/01546.pdf 
Nizar, Muhammad Afdi. (2020). Strengthening Sharia Banking through Merger or Consolidation Nizar, Muhammad Afdi Online at https://mpra.ub.unimuenchen.de/97964/ MPRA Paper No. 97964

Otoritas Jasa Keuangan, Definisi Stabilitas Sistem Keuangan, https://www.ojk.go.id/id/kanal/perbankan/stabilitas-sistemkeuangan/Pages/Ikhtisar.aspx 24 February 2021

Samuila, Asauten. (2015). The Effects of Mergers and Acquisitions on The Performance of Commercial Banks In Nigeria: Evidenced from United Bank for Africa (UBA) pls by Anderibom, International Journal of Education and Research Vol. 3 No. 4 April 2015 https://www.ijern.com/journal/2015/April-2015/10.pdf

Sarika and Vasantha. (2018). Motives and Drivers of the Bank Merger. International Journal of Pure and Applied Mathematics Volume 118 No. 5 2018, 167-174 ISSN: 1311-8080 (printed version); ISSN: $1314-3395$ (on-line version) url: http://www.ijpam.eu Special Issue, https://acadpubl.eu/jsi/2018-1185/articles/5/12.pdf , 168

Sekretariat Kabinet Republik Indonesia. (2020). Isi Perpu Kebijakan Keuangan Negara dan Stabilitas Sistem Keuangan Hadapi Covid-19,2020https://setkab.go.id/isiperpu-kebijakan-keuangan-negara-dan-stabilitas-sistem-keuangan-hadapicovid-19/

The Impact of Mergers and Acquisitions in the Banking and Insurance Sector, http://library.fes.de/pdf-files/netzquelle/01546.pdf

Tambunan, Toman Sony \& Wilson R.G. Tambunan. (2019). Hukum Bisnis, Jakarta, Kencana. 